Int. J. Electrochem. Sci., 15 (2020) $10262-10275$

International Journal of

ELECTROCHEMICAL

SCIENCE

WWW.electrochemsci.org

\title{
Applicability of Electrochemical Technology for Treating a Real Petrochemical Effluent by Electro-generated Active Chlorine Species
}

\author{
Jaqueline Ferreira de Melo ${ }^{1}$, Danyelle Medeiros de Araújo ${ }^{1}$, Djalma Ribeiro da Silva ${ }^{1}$, \\ Carlos Alberto Martinez Huitle, ${ }^{1, *}$, Paola Villegas-Guzman ${ }^{1,2}$ \\ ${ }^{1}$ Federal University of Rio Grande do Norte, Institute of Chemistry, Lagoa Nova, 59078-970 Natal, \\ RN, Brazil \\ ${ }^{2}$ Grupo de Investigación Navarra Ambiental, Fundación Universitaria Navarra, calle 10 No. 6-41, \\ Neiva, Huila, Colombia. \\ *E-mail: carlosmh@quimica.ufrn.br
}

doi: $10.20964 / 2020.10 .66$

Received: 17 April 2020 / Accepted: 18 August 2020 / Published: 31 August 2020

This work aims to investigate the treatment of a real petrochemical effluent (commonly named produced water (PW)) by electro-generated active chlorine species using $\mathrm{Ti} / \mathrm{Ru}_{0.3} \mathrm{Ti}_{0.7} \mathrm{O}_{2}$, $\mathrm{Ti} / \mathrm{Pt}$ and $\mathrm{BDD}$ anodes in a batch cell by applying $45 \mathrm{~mA} \mathrm{~cm}$. Chemical oxygen demand (COD) and spectrophotometric measurements were carried out to follow the elimination of organic matter as well as the concentration of active chlorine species was determined at the end of the treatment. Results clearly indicated that, removal efficiencies about $42 \%$ and $52 \%$, in terms of COD, were achieved with BDD and Ti/Pt anodes, respectively. Conversely, $\mathrm{Ti} / \mathrm{Ru}_{0.3} \mathrm{Ti}_{0.7} \mathrm{O}_{2}$ anode reached up to $85 \%$ of organic matter elimination, as consequence of the efficient production of active chlorine species $\left(\mathrm{ClO}_{2}-\mathrm{ClO}_{2}, \mathrm{Cl}_{2}\right)$ by the catalytic action of the anode during the electrochemical treatment.

Keywords: active chlorine, indirect electrochemical oxidation, mineralization organic matter, produced water.

\section{$\underline{\text { FULL TEXT }}$}

(C) 2020 The Authors. Published by ESG (www.electrochemsci.org). This article is an open access article distributed under the terms and conditions of the Creative Commons Attribution license (http://creativecommons.org/licenses/by/4.0/). 